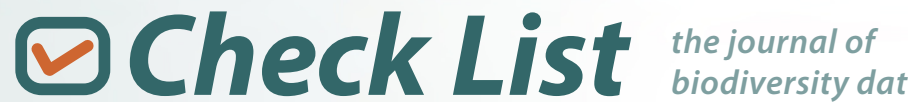

\section{Record of Electrona paucirastra Bolin, 1962 (Pisces: Myctophiformes: Myctophidae) in Brazilian waters, with comments on the occurrence of Electrona risso (Cocco, 1829) in the western South Atlantic}

\author{
Rodrigo A. Caires \\ Museu de Zoologia da Universidade de São Paulo, Seção de Peixes, Avenida Nazaré, 481, CEP 04299-970, São Paulo, SP, Brazil \\ E-mail: rodricaires@yahoo.com.br
}

\begin{abstract}
Electrona risso, a warm circumtropical lanternfish species distributed in all oceans, has been reported in the western Atlantic from Suriname to Southern Brazil. Re-examination of specimens attributed to this species which presumably supported the southernmost record in the western South Atlantic and are available at Museu de Zoologia, Universidade de São Paulo, Brazil, revealed that they were misidentified and are really Electrona paucirastra. As a result, E. paucirastra is reported for the first time in southern Brazil and the distribution of E. risso in the western Atlantic is discussed.
\end{abstract}

Key words: Electrona paucirastra; Electrona risso; distribution; southern Brazil

Electrona Goode \& Bean, 1896 is a genus of lanternfish with five valid species circumglobal in warm and southern cold seas (Bolin in Andriashev 1962; Becker 1963; Hulley 1986, 1990). Electrona risso (Cocco, 1829) has been recorded in the western South Atlantic from Suriname and northern Brazil, firstly by Nafpaktitis et al. (1977) based on a specimen hitherto not cataloged from LACM ichthyological collection, and further by Fujii in Uyeno et al. (1983) based on two specimens collected off Suriname and French Guiana. Although Santos et al. (2003) recorded E. risso for Brazil (to subtropical region), the specimens were collected outside Economic Exclusive Zone (EEZ) waters. In Santos et al. (2003) and Santos and Figueiredo (2008), the occurrence of this species in Brazilian EEZ was presumably supported by literature data.

Bernardes et al. (2005), in a book on fish species from the southeastern and southern sectors of Brazilian EEZ, briefly described and assigned E. risso to that region based on 16 specimens. However, the image in the book is clearly different from E. risso, and examination of some specimens examined by Bernardes et al. (2005), in MZUSP, revealed that specimens identified as E. risso are actually E. paucirastra Bolin 1962, the only Electrona species other than E. risso that is found north of the Southern Ocean. The objective of this study is to update the records of genus Electrona from the western South Atlantic.

Meristic and morphometric data follow Nafpaktitis and Nafpaktitis (1969). Measurements were made on the left side of the body with dial calipers and rounded to the nearest $0.1 \mathrm{~mm}$. Photophore terminology follows Nafpaktitis and Nafpaktitis (1969) and Paxton (1979). Institutional abbreviations follow Eschmeyer and Fricke (2015).

\section{Electrona paucirastra Bolin, 1962}

(Figure 1)

Material examined: MZUSP 98864, $1 \mathrm{spm} .(91.3 \mathrm{~mm}$ SL), RV Atlântico Sul, station 117: 34 $30^{\prime} 38^{\prime \prime}$ S, $051^{\circ} 49^{\prime} 04^{\prime \prime}$ W, 16 Ago. 2001; MZUSP 98865, 1 spm. (84.1 mm SL; Fig. 1), RV Atlântico Sul, station 119: $34^{\circ} 16^{\prime} 56^{\prime \prime} \mathrm{S}, 05^{\circ} 37^{\prime} 10^{\prime \prime} \mathrm{W}$, 17 Ago. 2001

Diagnosis: D 12; A 21, 22; P. 15, 16; lateral line scales 33, 39; gill rakers $6+17,7+17$. Photophore series: $\mathrm{PVO}$ 3; PLO 1; PO 4,5; VLO 3,2; VO 3,4; SAO 1; AOa 11, AOp 4, AO total 15; prc 2. Head length 28.7, $30.7 \%$ SL; body depth 21.6, 23.7\% SL.

Distribution: Southern circumglobal, from $34^{\circ} \mathrm{S}$ to $48^{\circ} \mathrm{S}$, at depths ranging from near surface to $100 \mathrm{~m}$ at night (Hulley 1986, 1990).

Only two of the 16 specimens examined by Bernardes et al. (2005) and identified by them as E. risso had been re-examined, but it is clear that they do not belong to this species. Electrona risso may be easily differentiated from its congeners by its deep body (body depth greater 


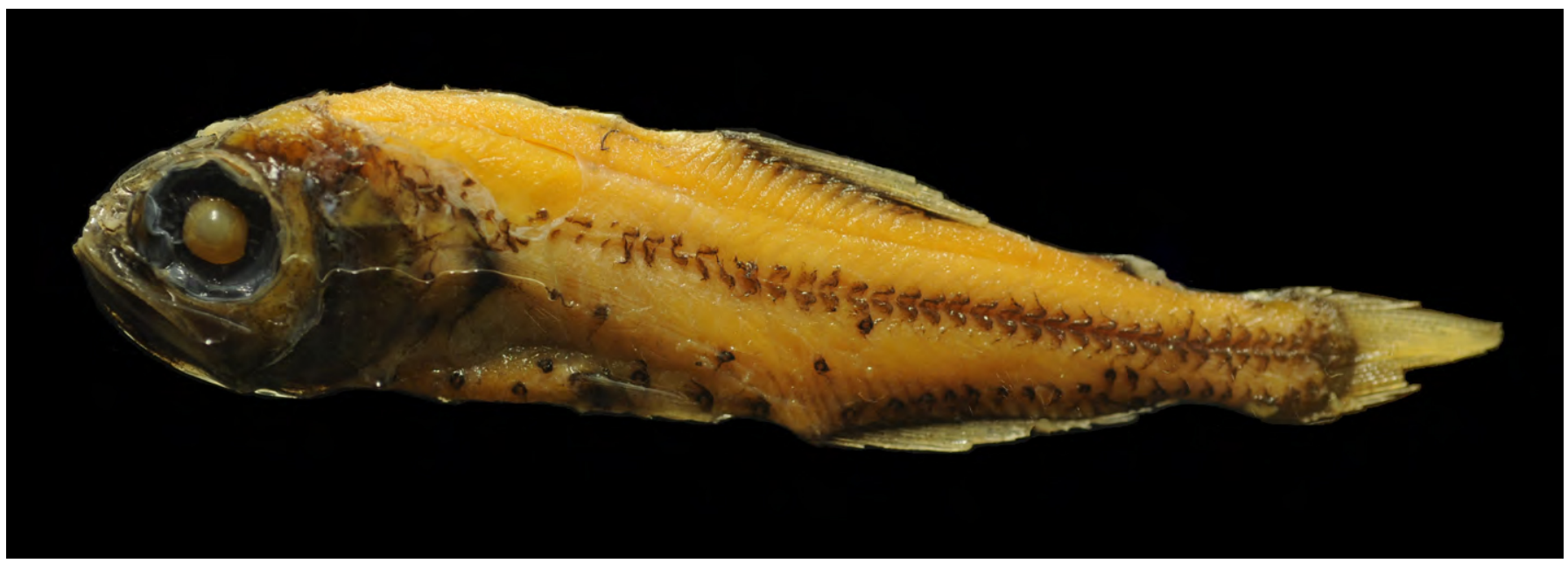

Figure 1. Electrona paucirastra Bolin, 1962. MZUSP 98865, $84.1 \mathrm{~mm}$ SL.

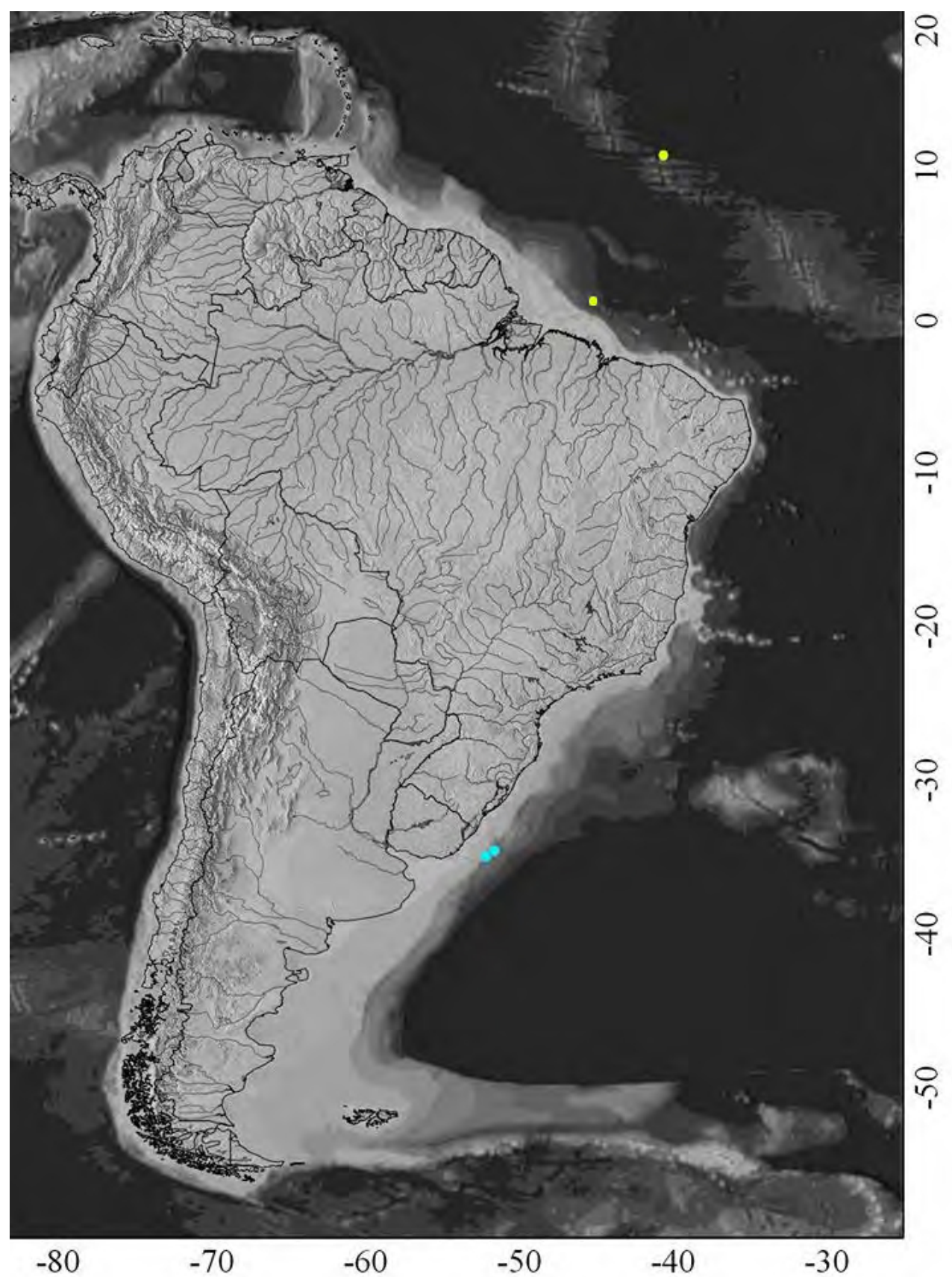

Figure 2. Distribution of Electrona paucirastra (blue circles) and possible records of E. risso (yellow circles) from the western South Atlantic. Data from yellow circles based on Nafpaktittis et al. (1977) and Santos et al. (2003). 
than or equal to $1 / 3 \mathrm{SL}$ ) and the low number of $\mathrm{AO}$ photophores (10-12). The two individuals examined herein are much lower (body depth less than 31\% SL) and possess 15 photophores on row $\mathrm{AO}$; differences in photophore counts could result from the poor condition of specimens. These specimens are recognized as Electrona paucirastra by the presence of $6-7+17$ gill rakers [8+16-19 in E. risso, 3-5+12-16 in E. antarctica (Günther, 1878) and 7-10+19-25 in E. carlsbergi (Tåning, 1932) and E. subaspera (Günther 1864)]. Also, they do not present SO photophore under eye, as in $E$. carlsbergi (Hulley 1986, 1990).

Santos et al. (2003) and Santos and Figueiredo (2008) recorded Electrona risso from Brazilian EEZ based on Nafpaktitis et al. (1977). They have also cited Becker's (1964) work on myctophid fauna collected in R/V Petr Lebedev expedition, and Hulley's (1981) findings on myctophids taken in Walther Herwig Atlantic trawls. Although no material from these expeditions and from Nafpaktitis and colleagues has been examined in the present study, a survey of species databases of many museums, particularly the Zoological Museum of Hamburg (where collections from Walther Herwig expeditions are housed) indicates that almost all records of lots identified as Electrona risso from the Atlantic have been taken outside Brazilian EEZ, including one lot from Museum of Comparative Zoology, Harvard University (MCZ 103083) cited by Santos et al. (2003) to substantiate the occurrence of this species in Brazil (Figure 2).

Based on available evidence, the occurrence of Electrona risso in Brazilian EEZ cannot be confirmed, since some material had not been cataloged and was not found. The record of this species off the northern Brazilian coast is based on Nafpaktitis et al. (1977).

\section{ACKNOWLEDGEMENTS}

I am indebted to Oswaldo Oyakawa, Aléssio Datovo and José Lima de Figueiredo (MZUSP) for allowing access to collections, and to Marcelo Melo, Michael Mincarone, Hudson Pinheiro and an anonymous reviewer by the valuable suggestions for improving the manuscript. Alexandre Marceniuk kindly made the distribution map.

\section{LITERATURE CITED}

Andriashev, A.P. 1962. Biological results of the Soviet Antarctic Expedition (1955-1958). I. Bathypelagic fishes of the Antarctic. I. Family Myctophidae. Issledovanija fauny morej = Explorations of the fauna of the seas. Rossijskaja Akademija Nauk, Zoologiceskij Institut 1 (9): 216-294.
Becker, V.E. 1963. New data on the lanternfish genera Electrona and Protomyctophum (Pisces, Myctophidae) of the Southern Hemisphere. Voprosy Ikhtiologii 3(1): 15-28.

Becker, V.E. 1967. The lantern fishes (Myctophidae) from the R/V Petr Lebedev Atlantic expeditions 1961-1964. Trudy Instituta Okeanologii 84: 84-124.

Bernardes, R.A., J.L. Figueiredo, A.R. Rodrigues, L.G. Fischer, C.M. Vooren, M. Haimovici and C.L.D.B. Rossi-Wongtschowski. 2005. Peixes da Zona Econômica Exclusiva da região sudeste-sul do Brasil: levantamento com armadilhas, pargueiras e rede de arrasto de fundo. São Paulo: Edusp. 304 pp.

Cocco, A. 1829. Su di alcuni nuovi pesci de' mari di Messina. Giornale di Scienze Lettere e Arti per La Sicilia 26(77): 138-147.

Eschmeyer, W.N. and R. Fricke. Catalog of fishes: genera, species, references. Accessed at http://researcharchive.calacademy.org/ research/ichthyology/catalog/fishcatmain.asp, 15 December 2015.

Hulley, P.A. 1981. Results of the research cruises of FRV 'Walther Herwig' to South America; LVIII. Family Myctophidae (Osteichthyes, Myctophiformes). Archiv für Fischereiwissenschaft 31: $1-300$.

Hulley, P.A. 1986. Family no. 86: Myctophidae; pp. 282-321, in: M.M. Smith and P.C. Heemstra (eds.). Smith's Sea Fishes. Johannesburg: Macmillan South Africa. 1047 pp.

Hulley, P.A. 1990. Myctophidae; pp. 146-178, in: O. Gon and P.C. Heemstra (eds.). Fishes of the Southern Ocean. Grahamstown: J. L. B. Smith Institute of Ichthyology. $462 \mathrm{pp}$.

Nafpaktitis, B.G., R.H. Backus, J.E. Craddock, R.L. Haedrich, B.H. Robison and C. Karnella. 1977. Family Myctophidae; pp. 13-265, in: R.H. Gibbs, F.H. Berry, J.E. Böhlke, D.M. Cohen, B.B. Collette, W.N. Eschmeyer, G.W. Mead, D. Merriman and T. Pietsch (eds.). Fishes of the western North Atlantic, vol. 7. Myctophiformes, pelagic zoogeography. New Haven: Memoirs of the Sears Foundation Marine Research 1(7): 1-302.

Nafpaktitis, B.G. and M. Nafpaktitis 1969. Lanternfishes (family Myctophidae) collected during Cruises 3 and 6 of R/V 'Anton Bruun' in the Indian Ocean. Bulletin of Los Angeles City Museum of Natural History 5: 1-79.

Paxton, J.R. 1979. Nominal genera and species of lanternfishes. Contributions in Science, Los Angeles City Museum of Natural History 322: 1-28.

Santos, A.P, J.L. Figueiredo and N.A. Menezes 2003. Família Myctophidae; pp. 52-57, in: N.A. Menezes, P.A. Buckup, J.L. Figueiredo and R.L. Moura (eds). 2003. Catálogo das espécies de peixes marinhos do Brasil. São Paulo: Museu de Zoologia da USP. 160 pp.

Santos, A.P and J.L. Figueiredo 2008. Guia de identificação dos peixes da família Myctophidae do Brasil. São Paulo: Edusp. 176 pp.

Uyeno, T., K. Matsuura and E. Fujii. 1983. Fishes trawled off Suriname and French Guiana. Tokyo: Japan Marine Fishery Resource Research Centre. 519 pp.

Received: 12 January 2016

Accepted: 13 May 2016

Academic editor: Hudson Pinheiro 